\title{
DRIVERS OF EUROENTHUSIASM OF NATIONAL POLITICAL ELITES: THE TEST OF THE EU ECONOMIC CRISIS 1
}

\author{
IRMINA MATONYTÉ2, GINTARAS ŠUMSKAS
}

\begin{abstract}
Undeniably, the economic crisis of 2008 was a critical juncture and a stress test for the EU and the Europeanness of its populations and elites. The crisis therefore offers an appropriate research setting for addressing two major research questions. In the following paragraphs, we first question how optimistic and unified the national political elites are towards the EU after the economic crisis of 2008. Second, we investigate which factors shape and drive the attitudes towards the EU of the national political elites.
\end{abstract}

KEYWORDS: elite attitudes; supranationalism; economic crisis of 2008; emotional and projective Euroenthusiasm; European regions.

\section{INTRODUCTION}

The phenomenon of Euroskepticism - its multidimensionality and multifaceted causes and effects - are widely discussed in academic research. The process involves the advent of EU-exacerbated dilemmas regarding national identities and nation-state governance versus the institutions, policies and affiliations of a supra-national character. Scholarly interest in the subject of Euroskepticism has risen in recent times after more Euroskeptics entered national parliaments and the EP, and especially when Brexit started in 2016.

\footnotetext{
1 This research was funded by the grant No MIP-025/2015 from the Research Council of Lithuania.

2 Irmina Matonyte, professor, ISM University of Management and Economics, Vilnius, Lithuania irmmat@ism.lt

3 Gintaras Šumskas, research fellow, ISM University of Management and Economics, Vilnius, Lithuania ginsum@ism.1t
} 
In parallel, studies that have identified positive attitudes towards the EU, support for a more integrated and enlarged Europe, multi-layered subjective Europeanization and an expanding sense of 'Europeanness' are flourishing, supplying rich descriptions and interpretations of the 'power of attraction' of the EU. These kinds of studies date back to the end of the Cold War and the signing of the Maastricht treaty. They received special impetus during the postcommunist enlargement of the EU and the period of protracted discussions regarding the Constitutional treaty of the EU. Empirical evidence implies that even the devastating economic crisis of 2008 did not have an unequivocally demoralizing impact on such positive appraisals. The results of the French presidential election in the summer of 2017, and the first public appearance of newly elected president Emanuel Macron to the tune of the EU anthem epitomize the vigorous pro-European mood.

The conceptual frameworks of these two seemingly juxtaposed bodies of research (Euroskepticism and positive Europeanness) take into account economic, ideological, electoral and socio-cultural elements and explore the underlying systemic drivers, thereby going beyond a superficial examination of the idiosyncratic features of national populations and elites.

The economic crisis of 2008 - and the time when this global financial crisis hit the EU - represents a particularly pertinent subject for the study of later shifts in Europeanness. However, even though the economic crisis of 2008 was an objective phenomenon (i.e. measurable in time and extent), it also had a constructivist dimension (by affecting public opinion, political discourse, and political behavior). Recent studies of Euroskepticism have found that the economic crisis of 2008, its length, the complexities of the bargaining process, and the unpopular nature of the solutions that were applied decreased support for the EU and boosted disappointment and disbelief in its mediating capacity among various constituencies (De Wilde - Zurn 2012). For instance, Brack and Startin (2015) consider that, because of the economic crisis of 2008, Euroskepticism has entered the mainstream and is now present across Europe at the level of public opinion - among political parties and civil society groups, within the EU institutions themselves, and in the media. However, other research demonstrates that even though the economic crisis of 2008 in the EU catalyzed the politicization of crisis management policies, spurred debates about the integration of the Eurozone and polarized opinions about the future of the EU it did not necessarily produce an indisputably downward trend in the support for the EU (Serricchio et al 2013; Armingeon - Ceka 2014; Teney 2016). 


\section{BRIEF REVIEW OF RESEARCH INTO THE EUROPEANNESS OF NATIONAL POLITICAL ELITES}

Research amply demonstrates that Euroskepticism, as well as positive Europeanness, are complex phenomena. This is particularly true for the elites, with their significant cognitive capacity and intricate engagement in EU affairs. Apprehending the attitudes of political elites is crucial for understanding the history and the future prospects of the EU. Indeed, national political elites (along with administrative, economic, media and social elites) play the dual role of being driving agents of the European integration process, and legitimating intermediaries before national citizens (Haller 2008; Sanders et al. 2012). The issues of the drivers and the scope of the Europeanness of national political elites became even more important after the EU underwent the economic crisis of 2008, which profoundly changed national and supranational political landscapes.

For a long time, pro-European, EU-supportive, loyal-to-the-EU sentiments and attitudes dominated among national political elites, and consequentially paved the way to and secured European unification. Comparative research from the pre-2008 crisis demonstrates that the Europeanness of elites is a relatively autonomous phenomenon: cues among political, economic and social segments of national elites have more impact on the Europeanness of peer elites, while the Euroskepticism of the masses has only a very limited effect (Best 2012, pp. 227-228). Dense national elite networks and strong embeddedness in EU affairs specifically drive national elites' Euroenthusiasm (Ginsberg 2010; Matonytė Morkevičius 2013). There are also regional differences in the patterns of elites' Europeanness, that depend on imperial and secessionist history (Lazic et al. 2012), on the length and the role of nation-states in EU building (Best et al. 2012), and on EU budget donor versus recipient status (Conti et al. 2010). Analysis of selected country cases shows that the positive Europeanness of elites in the post2008 crisis context did not undergo universal decline, although it was not crisisproof (Vogel - Teruel 2016).

Plausibly, the economic crisis of 2008 induced changes in elites' Europeanness and aligned it with the more Euroskeptic views of their national constituencies. The crisis necessitated that national and supranational political elites make a series of unprecedented decisions, leading to policies of domestic austerity, tense bargaining between creditor and debtor countries, and between the national governments and supranational organizations (Tsirbas - Sotiropoulos 2016; Magalhaes et al. 2016). In this elite-driven crisis-management process, the interests of some EU member states appeared to be conflicting and antagonistic, thus the efficiency of and trust in mediating EU institutions did not flourish. 
Yet, given that national elites are embedded into European networks and intensively socialize within the EU, the mindsets of national political elites were largely impermeable to national electoral grievances, exhibited strong positive Europeanness, and supported the supranational European agenda in response to 2008 crisis-aggravated problems. Thus, research that identifies trends in national political elites' Europeanness is of particular pertinence and relevance in the post-2008 crisis context.

\section{THE MULTIDIMENSIONALITY OF EUROPEANNESS, AND AN ANALYTICAL MODEL OF EUROENTHUSIASM}

Support for Europe and its multidimensionality have been widely discussed from different angles, using a variety of concepts. The notion of subjective Europeanization relates to the growing role of Europe in cognitive, affective and normative perceptions and orientations, as well as highlights that European citizens nolens volens develop complex feelings, expectations and interests towards the EU (Mau - Verwiebe, 2010). Researchers distinguish between abstract and concrete, static and dynamic elements of support or opposition to the EU (Beaudonnet - DiMauro 2012). Europeanists agree that overall support for the EU is based on compound stances: affective (such as the sense of belonging or identification), cognitive (such as the subjective perceptions and meanings attached to the EU) and evaluative (Best et al. 2012). Analysis of the fit between theoretical conceptualization and measured attitudes reveals that European identity and support for the EU are a complex phenomenon, the discrete dimensions of which may engage different logics and produce conflicting trends (Beaudonnet - DiMauro 2012). Different weights are assigned to emotional and cognitive factors, and their eventual interplay (Lubbers - Scheepers 2010; Recchi 2014; Teney 2016). In diverse national contexts, distinct sets of primordial and civic characteristics of European identities have been documented (Göncz - Lengyel 2009).

Scholars distinguish several layers of EU-related sentiments and attitudes. Drawing on the concept of diffuse and specific support, Matthew Gabel in 1998 proposed a model of pro-EU stances, grouped along utilitarian and affective dimensions, the former shaped by governing authorities and political values, and the latter embracing abstract values and commitments to the ideal of an integrated Europe. 
In a study of the post-communist enlargement of the EU, Kopecký and Mudde (2002) differentiate between support and opposition for the idea of European integration in principle, and attitudes towards the EU as the current embodiment of this idea. The authors also draw on a distinction between diffuse and specific support, and propose a four-fold classification of attitudes towards the EU. Within the concept of diffused support, Kopecký and Mudde distinguish between Europhiles, who cherish the idea of European integration, and Europhobes, who oppose the entire concept of EU unification. Along the dimension of specific support, there are EU-optimists and EU-pessimists. Among the EU-optimists there is a continuum of Euroenthusiasts - Europragmatists, which differentiates the degree of endorsement for the idea of the EU and the operational ways it develops. EU-pessimists may also be located on a continuum, ranging from Euroskeptics (who like the abstract idea of the EU but are dissatisfied with its functioning), to Eurorejects (who oppose the EU in principle). This four-fold classification of attitudes towards the EU has contributed to the abstract-valuesversus-political-strategy debate, showing that European ideology prevails as the dominant explanation for positive Europeanness, although political strategy at times explains specific forms of support. Even though the terms themselves imply the existence of emotional content, Kopecký and Mudde overlook the affective side of Europhilia and Europhobia. Further studies have partially addressed this omission.

For instance, the concept of Europeanness developed by Best, Lengyel and Verzichelli (2012) comprises the idea that there coexist different dimensions of attitudes (emotions, cognitions, evaluations and expectations), and objects (institutions, policies, strategies) related to the EU, and that their appreciation differs. The emotional aspect of Europeanness captures affective attachment to Europe. The cognitive-evaluative dimension of Europeanness reflects concerns relative to EU governance (approval or disapproval of current trends). The projective dimension of Europeanness captures support for the supranational policy development of the EU in the future.

Extending earlier work on the structure of attitudes towards the EU, authors of the most recent study of Europeanness claim that there are at least five complementary aspects of attitudes towards the EU: attitudes towards its performance and identity, feelings of affection, values of utilitarianism, and support for its strengthening (Boomgaarden et al. 2011). The scholars consider as utilitarian evaluations of the functioning of the EU and matters of strengthening European integration; in contrast, affective attitudes include emotional responses, identity-related factors and perceived threats to the nation. The authors also underline that negative emotions are important as they convey feelings of fear and the threat posed by the EU, and they empirically show that 
negative affection is very sensitive to economic expectations. Boomgaarden et al. 2011 demonstrate that a relatively large share of support for Europe depends on sentiment, yet the utilitarian dimension (related to the immediate performance and the democratic and financial functioning of the EU and its institutions) is dominant among European citizens. As to future EU strengthening, distinguished as a separate issue, this dimension is also attracting the attention of other researchers who observe that, because of the growing politicization of the EU, projective stances towards the EU are becoming more salient (Teney 2016).

For the purposes of this study, designed to clarify the shift in the attitudes of national political elites towards the EU caused by the economic crisis of 2008, we consider it important to underline two aspects of Europeanness which are under intensive debate, yet which are under-researched in European studies. These are the emotional and the projective dimensions of Europeanness.

As to the first one, the classical definition of social identity refers to the part of an individual's self-concept derived from their knowledge of their membership of a social group (or groups), together with the value and emotional significance attached to that membership (Tajfel 1978, p. 63). Social identity theory acknowledges and underlines the fact that such categorizations breed in-group bias and positive emotions. Affectively, collective identities provide a sense of pride in and belongingness to a group, and reflect the value of that identity to the group member. Authoritative social psychologist Frijda (2007) forcefully claims that emotion is in fact what happens when individuals evaluate themselves, and when they evaluate the goodness or rightness of organizations and collectivities to which they belong and with which they identify. This is why emotions are central to understanding collective identities. However, for quite a long time the social research of collective identities has followed and reflected the fashionable notion of the "cognitive revolution" (Deaux 1996) and ignored concerns about affective issues. Therefore, it was natural that identity researchers finally addressed the pressing need to integrate emotions into their definitions and models. Affective identification is associated with positive feelings about one's membership, including pride, enthusiasm, and a sense of affiliation or belongingness (Albert et al. 1998). The direct experience of emotions and the personal value of one's identity comprise affective identification, defined as the feeling that individuals experience about themselves in relation to a reference category, and the value they place on that reference community. Collective identities are not merely cognitive constructions; people also attach varying levels of emotional significance to their reference categories, and the affective dimension of attachment and identification is prominent. The emergence and operation of a particular collective identity means that other identities diminish 
in relevance and salience. Social identities typically only function as orientation markers, and only when they are activated affectively do they transform into collective identities. Accordingly, it is not so much normative as emotional triggers that ground the choice and expression of a particular collective identity (Snow 2001).

The indicators, which juxtapose national and European sentiments, thus, effectively capture the strength, substance and relevance of European identification and the prevalence of European interests over national concerns, as well as the sense of fairness about European decision-making. Even though some research shows that on the level of individual attachment national and European identities may coexist (Risse - Grabowsky 2008; Medrano 2010; Kaina et al. 2016), issues of national pride and EU fairness play a role in the highly relevant contradiction between feelings about national and European (i.e. other EU member states') matters. While the attribution or avowal of all identities is interactionally contingent, collective identities tend to be more fluid, tentative, and transient than categorically based social identities or personal identities (Snow 2001). The malleability of European identity should be particularly perceptible through the variable of emotional attachment, observed under conditions of critical juncture.

During periods of crisis, the flexibility of the projective dimension of Europeanness should also increase. On this point, noting that collective identities arise and operate within an interactive context marked by uncertainty and power relationships, Emmanuel Castells distinguishes three types of identities: legitimizing, resistance, and project (Castells 1997, pp.7-10). Legitimizing identities are associated with dominant institutions, whereas resistance and project identities represent two competing vectors. Devalued collectivities generate identities of resistance. In contrast, project identities construct alternative identities and support new systems that valorize rather than defy the new identity. Castells emphasizes that this triplet of collective identities is interactive and contextually embedded. Applied to Europeanness, resistance identity conveys the traditional concerns of the nation state and feeds Euroskepticism, while project identity leads to EU strengthening and supranational governance. Indeed, some researchers find that support for Europe is less justifiable in terms of nation-state based rationality than by expectations related to institutional mechanisms that organize preferences at the EU level (Best el al 2012). Therefore, the projective dimension of elites' Europeanness is vital. Analysis of support for the delegation of national sovereignty and the creation of the supranational layer of EU governance captures the status of the triplet of collective identities (distinguishing between status quo-resistanceand-projective orientations), as elaborated by Castells (1997). The main 
European institutions (the European Parliament, the Council of Ministers, and the European Commission) embody legislative powers (national, partisan constituencies and the European demos), executive political leadership and supranational bureaucratic and technocratic expertise. These institutions could not withstand undergoing revision due to the 2008 crisis. Concomitantly, the Lisbon treaty (in force since 2009) introduced new institutional dynamics, rearranging the relations of the three major political actors on the level of the EU: national governments, the EP and the EC. What trends in the development of resistance versus project identities has the double trigger (the economic crisis of 2008 cum constitutional reform of the EU) engendered among elites? Prior to the economic crisis of 2008, the elite perspective was not as nationally introverted as one may suspect. Country and regional differences were relevant, but support tended overall to skew towards the upper half of the strengthening supranationalization scale (Cotta and Russo 2012). Notably, Germany together with the Southern European member states were the main supporters of the supranationalization of EU policies, while CEE countries were less in favor of deeper policy integration, except in foreign policy (Real-Dato et al.2012). The question arises if the economic crisis of 2008 moderated (or inverted) the extrovert Europeanness of national elites.

Post-crisis empirical research shows that supranational redistributive policy development and integration finds no strong resistance on the EU level; however, the positions of different member states are distinctly clustered (Vogel - Teruel 2016). The supportive stance of poorer countries and those hit harder by the 2008 crisis is rational, because of the positive gains that would arise from the communitarization of the redistributive policy field, including unified taxation, social security and targeted economic assistance. However, the similarly enthusiastic attitudes of the German elites appear less justified by utilitarianism and more by devotion to the very idea of the EU and the principle of deeper integration. Yet, the more reticent stances towards the supranationalization of redistributive policies by the CEE elites are still attributable to newly regained sovereignty and the willingness to exercise it (Słomczynski - Wesołowski 2010).

\section{A MODEL OF EUROENTHUSIASM, COMPARATIVE DATA FROM NATIONAL POLITICAL ELITES, 2014-2007}

In this research paper that focuses on the effects of 2008 crisis, we find it opportune to use the more precise term Euroenthusiasm - which implies positive emotional relations and supportive projective assessment - instead of the wider terms Europeanness or subjective Europeanization that are applicable to long - 
and medium - time horizons and general dynamic developments. As in Kopecký and Mudde (2002), the term Euroenthusiasm captures operational support for the EU, and the normative ideal of ever-closer union. Even though Kopecký and Mudde underscore the affective dimension, the term Euroenthusiasm semantically involves pragmatic calculus and engages emotions. The term Euroenthusiasm also conveys comprehensive support and investment in the EU and positive future projections.

Our model of Euroenthusiasm underlines two major features. First, we emphasize and expand the measurements of the emotional dimension of Euroenthusiasm by adding two variables to the core emotional variable of "attachment to Europe". We take into the account the factors of national pride and the fairness of EU decision-making. The original model of Europeanness (Best et al. 2012) included an assessment of the EU benefits to member states as a sign of emotional Europeanness. However, we discount this since attitudes towards EU benefits are more general and less time (crisis) sensitive (indeed, the question "if your country benefited from EU membership?" generated in both 2007 and 2014 around 90\% positive responses among all national elites). Meanwhile, the variables of national pride and EU fairness are sensitive to the temporal specificities of national political and policy-making processes. For instance, national elites' agreement with the statement "those who make decisions at the EU level do not take enough account of the interests of [country] at stake" in 2007-2009 significantly decreased their support for the supranationalization of public policies (Matonytė - Morkevičius 2013, pp. 162163). Moreover, before the crisis of 2008 agreement with the statement "the interests of some member states carry too much weight at the EU level" was rather insignificant in relation to support for supranational policy governance (Matonytė - Morkevičius 2013, pp. 167). However, it is plausible that the 2008 crisis might also have exacerbated the feeling that other countries are taking advantage of one's own country hardships (for instance, Germany versus Greece). In the dataset from 2014, the question associated with national pride "those who make decisions at the EU level do not take enough account of the interests of [country] at stake" generated a result of 60/40, while its ratio in 2007 was 50/50. Second, instead of employing an equilibrated account of retrospective and prospective views, we focus on projective support and positive stances towards the future strengthening of the EU institutions and the supranationalization of redistributive policies (over 10 years). In our model of Euroenthusiasm, we downplay retrospective evaluations and assessments of the current situation of the EU as too general, and presumably less susceptible to the effects of the crisis. Therefore, we work with a narrow range of indicators that tap into the positive and negative emotions generated by the EU, support for 
the strengthening of EU-level institutions, and the development of supranational EU policies. We use the term 'Euroenthusiasm' to highlight the emotional component of support for the EU and the projective appreciation of the idea of an ever-closer union. Yet it should be underlined that the empirical indicators also imply pragmatic evaluations and cognitive judgement.

Drawing on data from IntUne (2007) and ENEC-2014, our study contrasts the data from two waves of political elite surveys conducted in nine EU member states: two Western European countries (founding or West European states of the EU: Germany, France), four SE countries (Italy ${ }^{4}$, Greece, Portugal and Spain) and three CEE countries (Lithuania, Hungary and Bulgaria). Case selection for the three reference groups is due to data limitations - only these nine EU countries participated in both surveys (Table 1). Sample sizes in individual counties are similar (quota of 70 parliamentarians per country, in the cases of small parliaments, 50). The total sample size used in the regression analysis is $\mathrm{N}=1349$.

Table 1. Countries and respondent groups

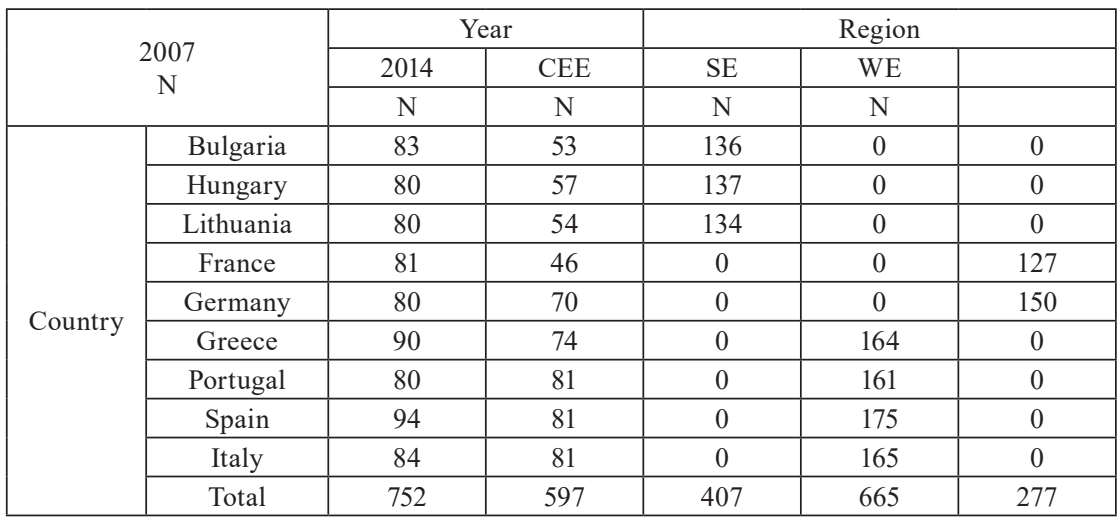

The concept of national political elites' Euroenthusiasm is operationalized as an aggregate measurement, with a focus on national political elites' answers to eight questions (See Table 2) grouped into two sub-sets: emotional relation to the EU, and projective stances towards the strengthening of EU-level institutions and the supranationalization of redistributive policies. The emotional dimension of Euroenthusiasm includes three variables that capture individual attachment

\footnotetext{
4 Italy is a mixed case, belonging to both WE and SE regions. Yet, objectively, the 2008 economic crisis hit Italy in a similarly hard way as other countries in the SE. Even though Italy is a founding member of the EU, in terms of geography and culture Italy belongs to the SE region.
} 
to the EU (positive emotion) and two sociotropic evaluations (negative emotion laden) relating to national pride and the fairness of EU decision-making. The projective dimension is measured using five variables: two concerning the further strengthening of EU institutions, and three measuring support for the supranationalization of taxes, social security and help for EU regions.

Principal component factor analysis revealed that the eight indicators cluster into two groups, which in further analysis will be referred to as emotional and projective (see Figure 1). The Cronbach's Alpha of our model of Euroenthusiasm is 0,604 .

Figure 1. The emotional and projective components of Euroenthusiasm (factor loadings; all countries) (2007 - 2014)

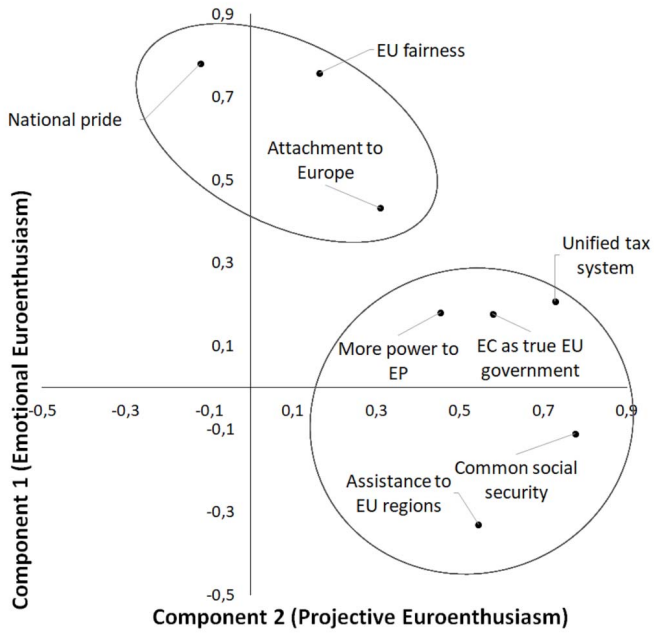

Overall, during 2007-2014 the Euroenthusiasm of national political elites underwent recognizable changes (Figure 2). The biggest positive change (increase in Euroenthusiasm) occurred in Germany, while the biggest negative change (decrease in Euroenthusiasm) occurred in Greece and Hungary. Tangible changes occurred in both the emotional and the projective dimensions. For example, the emotional dimension of Euroenthusiasm underwent a positive (upward) movement in Lithuania, but declined in Spain, Greece and Portugal. As for the projective dimension, positive changes prevailed in Germany and Italy, and negative in Bulgaria and Hungary. On an aggregate level, Euroenthusiasm in 2007-2014 was the most stable among elites in France. 
Figure 2. Changes in Euroenthusiasm (indexes) (2007 - 2014)

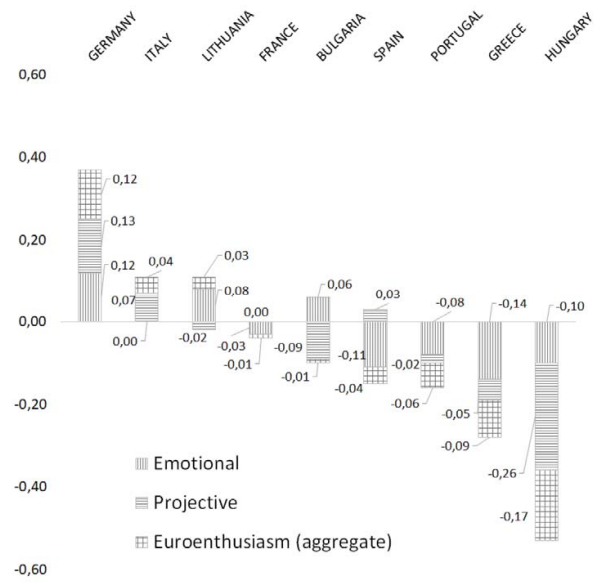

As for the regional patterns and the length of EU membership (Figure 3), political elites from the West-European EU member states (Germany and France) emerged from the crisis more Euroenthusiastic than before it. Meanwhile, the emotional Euroenthusiasm of SE elites significantly declined, while their projective Euroenthusiasm remained stable. The Euroenthusiasm of CEE elites slightly increased on the emotional dimension, but the overall tendency was to a decrease because of a tangible drop in projective Euroenthusiasm.

Figure 3. Changes in Euroenthusiasm by region (WE, SE and CEE) (2007 - 2014)

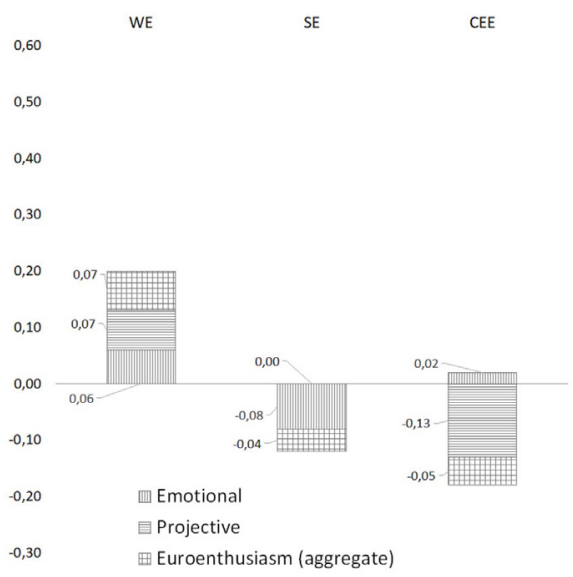


As to the extremism of political ideologies (Figure 4), the data show a clear tendency: the greater the radicalism of national political elites, the weaker their Euroenthusiasm.

Figure 4. Euroenthusiasm according to extreme versus moderate political views (2007-2014)

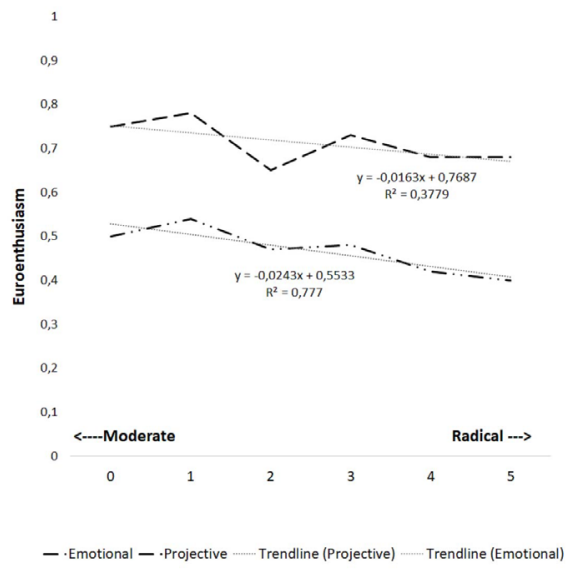

* Recoded 0-10 ideological self - identification scale where 0 represents moderate (center scale) and 5 represents extreme (extreme left and right) ideological identities

Finally, the descriptive analysis shows that, across Europe, the incumbent national political elites throughout 2007-2014 were perceptibly more Euroenthusiastic than were representatives from the political opposition (Figure 5). The biggest difference between politicians who were in government and opposition politicians related to their emotional Euroenthusiasm $(0.11$ points), while the difference in projective Euroenthusiasm was rather small (0.05 points). 
Figure 5. Euroenthusiasm by party in power versus opposition (2007 - 2014)

III Emotional 目Projective $⿴$ Euroenthusiasm (aggregate)

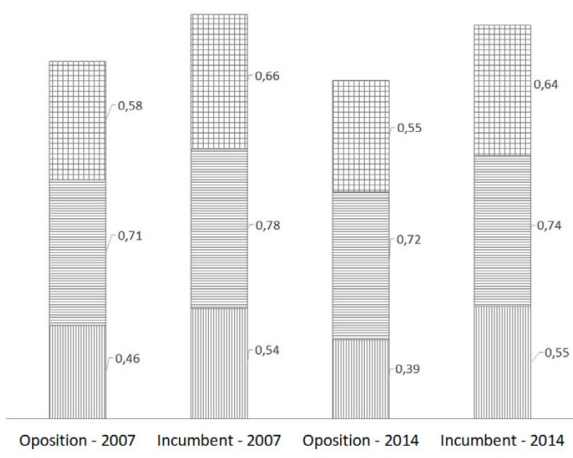

\section{THEORETICAL PREMISES FOR THE CAUSAL ANALYSIS OF SHIFTS IN EUROENTHUSIASM, 2007 - 2014}

Inspired by the insights from the descriptive statistics, we review arguments that go beyond the nation-state level and offer a systemic explanation why and in which direction the emotional and projective Euroenthusiasm of national political elites might have changed because of the economic crisis of 2008 .

\section{Explanatory variables}

Region and length of EU membership and their impact on Euroenthusiasm is a very broad and complex subject that includes cultural, historical, social, economic and political components. Our descriptive analysis (see Figure 1) reveals slightly different patterns of Euroenthusiasm in three regions (WE, SE and CEE). The distinction between three EU regions is based on a macro-level divide that takes into account the functional integration of national polities, economies and social structures. The longer the EU membership (i.e. tenure), the greater the integration and presumably the smaller negative effects of the economic crisis of 2008. The regional aspect differentiates latecomer CEE 
countries (relatively poor economies, integrated into the EU in the neo-liberal spirit) from SE countries (moderately well off economies, integrated into the EU in the 1980s due to social market concerns) and WE countries (the richest economies in the EU, who cherish socio-economic solidarity).

The Cold War created the division between East and West that is reflected in the distinct political conflict between CEE versus old(er) EU memberstates relative to European integration, based on different patterns of political, economic and cultural development (Vaughan-Whitehead 2003; Steenbergen -Marks 2004). More studies are emerging that empirically document the legacy of the state-socialist regimes, thereby characterizing the post-communist EU member states twenty and more years after the fall of the Berlin Wall (Pop-Eleches - Tucker 2017). According to the theory of the varieties of capitalism, CEE countries adopted a specific form of capitalism (Hall and Soskice 2003, Hay 2004, Schubert et al. 2009). Characterized by a liberal state, an economy dependent on foreign direct investment and foreign firms, and a technological gap, CEE countries have a special type of dependent market economy (Hancké et al. 2007, Nölke Vliegenthart 2009) in which economic openness and significant exposure to internationalization combines with nationalistic values. This paradoxical combination of economic globalization and nationalistic values is solidly established among the Baltic elites (Steen 2015), but is less sustainable in other CEE countries, as the epic drives towards political conservativism in Poland and Hungary now indicate. In contrast, earlier studies show that less nationally minded and broadly pro-European political elites rule Southern member states (Conti et al. 2010). However, the economic growth in both the SE region and CEE countries which occurred after their joining the EU is based on infrastructural development, often financed by EU transfers (Magone 2003, Magone 2011; Ó Beacháin et al. 2012). Objectively, SE countries endured the greatest economic hardships during the crisis of 2008. Therefore, in SE countries the issue of Europe might have become very divisive and produced the strong incentive to increase national ownership and control of lives and livelihoods within the EU.

Meanwhile, CEE countries immediately after their integration into the EU stood out as being notoriously reluctant to supranationalize, enjoying their recently regained national sovereignty (Słomczynski - Wesołowski 2010). The commitment of CEE countries to the principle of ever-closer union appears dubious and their attitude towards the EU often confirms Haller's definition (2008) of their instrumental position: "it's taking part that counts". The absence of clear, deep-seated positive affection for the EU under conditions of critical juncture may also ultimately decrease projective Euroenthusiasm. 
Table 2. Variables and coding

\begin{tabular}{|c|c|}
\hline $\begin{array}{l}\text { Variable } \\
\text { Name }\end{array}$ & Measurement/ Coding \\
\hline $\begin{array}{c}\text { Dependent } \\
\text { variables }\end{array}$ & \\
\hline $\begin{array}{l}\text { Dependent } \\
\text { variable } \\
\text { EU } \\
\text { enthusiasm } \\
\text { and } \\
2 \text { composite } \\
\text { sub-indexes }\end{array}$ & 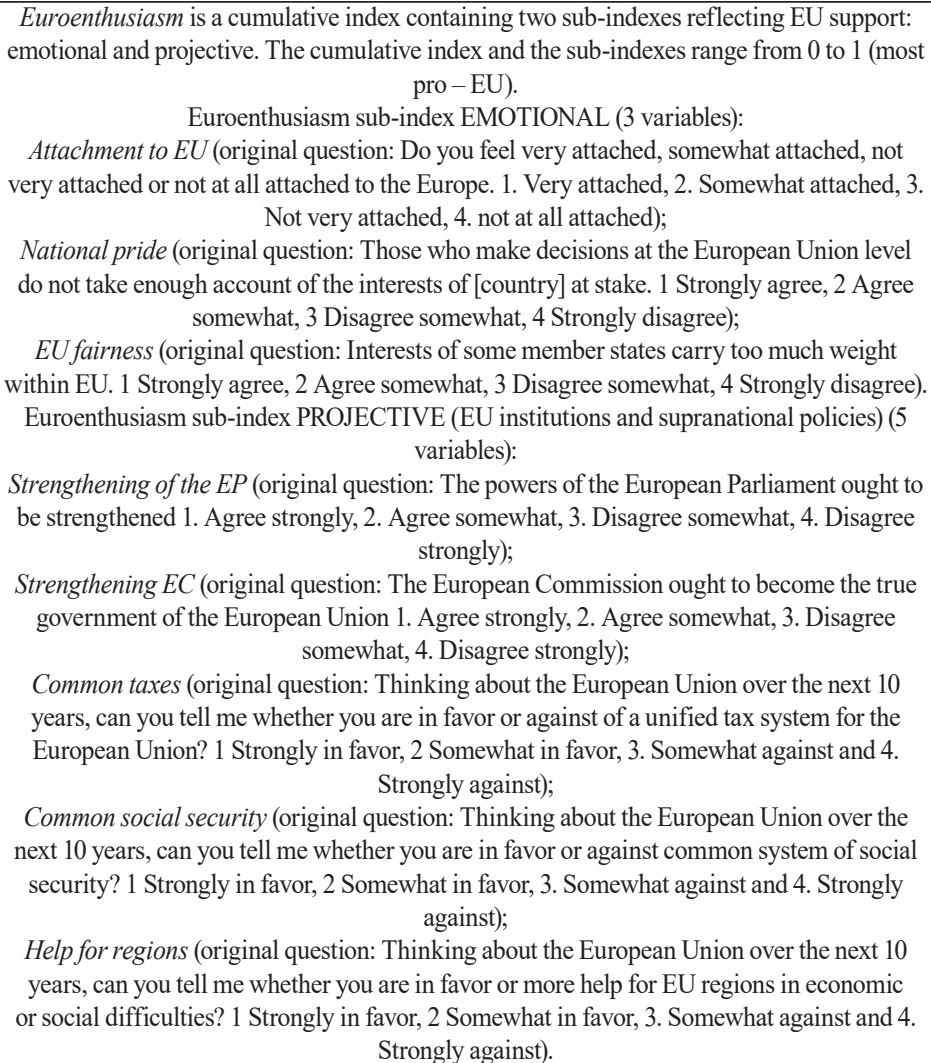 \\
\hline \multicolumn{2}{|r|}{ 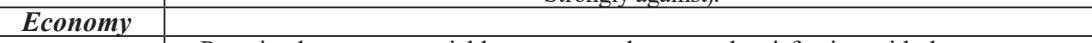 } \\
\hline $\begin{array}{l}\text { Perceived } \\
\text { economy }\end{array}$ & $\begin{array}{l}\text { Perceived economy variable represents the general satisfaction with the economy. } \\
\text { Based on the change of Consumer Confidence Indicator (CCI), optimistic periods } \\
\text { (relative growth of CCI score) coded as 1, negative CCI changes coded as 0. Consumer } \\
\text { confidence indicator uses selected questions addressed to consumers according to the } \\
\text { Joint Harmonized EU Programme of Business and Consumer Surveys. } \\
\text { Source: European Commission - Directorate general for economic and financial } \\
\text { affairs (DG ECFIN): } \underline{\text { http://ec.europa.eu/budget/figures/interactive/index en.cfm }} \\
\left.\text { (access date: January } 6^{\text {th }}, 2016\right) \text {. } \\
\text { More details on the consumer confidence indicator as well as long time series can } \\
\text { be found via the following link: http://ec.europa.eu/economy_finance/db indicators/ } \\
\text { surveys/index en.htm }\end{array}$ \\
\hline
\end{tabular}




\begin{tabular}{|c|c|}
\hline Crisis & Dummy variable for post-crisis 2014 coded as $1 ; 0$ for 2007. \\
\hline Ideology & \\
\hline $\begin{array}{l}\text { Left - Right } \\
\text { scale self- } \\
\text { identification }\end{array}$ & $\begin{array}{c}\text { Original Question: On a left-right scale where } 0 \text { means the left and } 10 \text { means the } \\
\text { right, where would you place yourself? }\end{array}$ \\
\hline $\begin{array}{l}\text { Political } \\
\text { radicalism }\end{array}$ & $\begin{array}{l}\text { Political radicalism score represents the level of affinity to left or right ideology. } \\
\text { The score is a refined left - right scale where the extreme values of the scale ( } 0 \\
\text { and 10) are re-coded as 5, } 1 \text { and } 9 \text { re-coded as } 4,2 \text { and } 8 \text { re-coded as } 3,3 \text { and } 7 \\
\text { re-coded as } 2,4 \text { and } 6 \text { re-coded as } 1 \text {, and the neutral middle scale } 5 \text { recoded as } 0 \text {. }\end{array}$ \\
\hline $\begin{array}{l}\text { Electoral } \\
\text { calculus }\end{array}$ & \\
\hline $\begin{array}{l}\text { Incumbency } \\
\text { versus } \\
\text { opposition }\end{array}$ & $\begin{array}{l}\text { Coded } 1 \text { for representatives of governing parties and } 0 \text { for opposition. } \\
\text { Original question: Party in government at the period of survey. }\end{array}$ \\
\hline $\begin{array}{c}\text { Election } \\
\text { period }\end{array}$ & $\begin{array}{l}\text { Coded } 1 \text { if country held national parliamentary elections during or one year after } \\
\text { survey year and } 0 \text { if election dates did not correspond with the survey period. }\end{array}$ \\
\hline Socialization & \\
\hline $\begin{array}{l}\text { EU Tenure } \\
\text { (Maturity) }\end{array}$ & $\begin{array}{c}\text { Variable represents the length of EU membership. } \\
\text { EU founding countries (Germany, France and Italy) coded as 3, Southern Europe } \\
\text { countries (Greece, Portugal and Spain) coded as } 2 \text { and Central East European } \\
\text { countries (Lithuania and Bulgaria) coded as } 1 .\end{array}$ \\
\hline $\begin{array}{l}\text { Professional } \\
\text { Contacts }\end{array}$ & $\begin{array}{c}\text { Original Question: How frequently, in your political activity, were you in contact } \\
\text { with actors and institutions of the EU in the last year? } 1 \text {. At least once a week, } 2 . \\
\text { At least once a month, 3. At least once every three months, } 4 \text {. At least once last } \\
\text { year, } 5 \text {. No contacts last year. }\end{array}$ \\
\hline \begin{tabular}{|c|}
$\begin{array}{l}\text { Residence in } \\
\text { EU }\end{array}$ \\
\end{tabular} & $\begin{array}{l}\text { Original Question: Have you ever lived in another European country? (at least } 3 \\
\text { months) } 1 \text {. Yes, } 2 \text {. No. }\end{array}$ \\
\hline $\begin{array}{l}\text { European } \\
\text { regions in } \\
2007 \text { and } \\
2014\end{array}$ & \\
\hline $\begin{array}{c}\text { Western } \\
\text { Europe (WE), } \\
\text { new Southern } \\
\text { Europe (SE) } \\
\text { and Central } \\
\text { and Eastern } \\
\text { Europe (CEE) }\end{array}$ & $\begin{array}{l}\text { National political elites' samples from in } 2007 \text { and } 2014 \text { Western Europe } \\
\text { in } 2007 \text { and } 2014 \text { (France and Germany); Southern Europe (Italy, Greece, } \\
\text { Portugal and Spain) and Central and Eastern Europe (Bulgaria, Hungary and } \\
\text { Lithuania). Total sample N=1349 (N=752 in } 2007 \text { and N=597 in 2014). }\end{array}$ \\
\hline
\end{tabular}

In contrast, earlier research shows that elites from Germany and France, the leading EU member states, are the stronghold of support for European integration (Best et al 2012). The Lisbon treaty, which has since 2009 intentionally strengthened EU institutions and common policies, was the result of the perseverance of German and French politicians. The question is if the elites in these countries preserved their staunchly pro-EU stances after the crisis. After all, these better off countries might be reluctant to make the investment needed to rescue the most crisis-affected countries, and - instead 
of the long-established, positive-sum-game governance of EU affairs - France and Germany might enter a period of multiple zero-sum game playing and renationalization (as another affluent EU member state, the United Kingdom, is doing with Brexit).

H1. Length of EU membership increases Euroenthusiasm.

Socialization in the EU covers the cultural-emotional, professional and social components of elites' experiences and relations to the EU. The idea that socialization in the EU might have an effect on values and preferences is drawn from Bourdieu's theory that socializers engage in the exchange and dissemination of particular sets of concepts and behavioral dispositions that shape the ways in which people feel, think about and act in the world (Checkel 2005). Thanks to the power of normative persuasion, socializers adapt and refashion their identities and outlooks accordingly. In contrast to strategic calculation, the socialization approach implies that attitudes and behavior have a normative and emotional basis (Schimmelfennig 2005). Research shows that direct and indirect transnational experience and participation in European networks has an effect on elites' Europeanness (Best et al., 2012; Matonytė - Morkevičius 2013). Taking into account the regional differences, EU socialization applies primarily to newcomers from CEE, since they are expected to absorb the values and habits of the WE elites who comprise the 'Club of Founders'.

H2: EU socialization increases the level of Euroenthusiasm.

A political-ideological variable indicates how ideological mind-sets (left-wing versus right-wing preferences) affect Euroenthusiasm. European integration is a multi-dimensional process that shapes identification with a polity, affects the ideological priorities related to the mechanisms of political representation, democratic control, policy scope and the extent of economic redistribution (Bartolini 2005, Best et al. 2012). Research reveals that left-leaning elites more enthusiastically support the EU than the right-leaning elites (Hooghe et al., 2002; Matonytė - Morkevičius 2013). Left-wing parties might oppose EU integration because of the neoliberal character of the EU, while right-wing parties out of concern for national sovereignty.

H3. Left-leaning political ideologies positively affect Euroenthusiasm.

The moderate versus extremist political views variable also taps into the field of political culture. The European menu is rich, and different parties choose different dishes from it in line with their own agendas and policy priorities (Sitter 2001; Neumayer 2008). Only the extreme (marginal) positions are simple, while the mainstream parties express a variety of moderate positions. It has been 
established that the association between a political party's position on European unification and its ideological stance takes the form of an inverted U-shaped curve: the further from the center of the left-right axis a party positions itself, the likelier it is that it will oppose European integration (Hooghe et. al., 2002; Hooghe et al. 2006). Parties on the radical left and the radical right tend to be Euroskeptic in order to demarcate themselves from their more moderate competitors (Taggart, 1998).

Because of the economic crisis of 2008, radical populist parties emerged in substantial numbers across the EU. However, these parties are not internally cohesive, and - referring to Kopecký and Mudde's terminology (2002) they encompass several factions, including Euroskeptics, Europragmatists and Eurorejects. The issue of European integration is very divisive for these radical parties. On the one hand, as a means of breaking into the electoral market (Rohrschneider -Whitefield 2016) these radical parties have the specific incentive to increase their ownership of EU issues, but on the other, they seek to offer clear policy stances about sensitive national matters.

Pre-crisis research shows that political extremism has the biggest (negative) impact on Europeanness and that centrist attitudes correlate with stronger Europeanness (Best et al. 2012). Given that the economic crisis of 2008 has increased the politicization of domestic and EU issues, and that the views of national elites might have become more polarized, an increase in the intensity of conflict over European integration is to be expected (De Wilde 2011). The absorption of European integration into domestic party competition involves the type of polarization that is connected to the positions of mainstream or centrist parties' vis-à-vis radical and extreme parties.

\section{H4. Political extremism negatively affects Euroenthusiasm.}

The variable party in government versus opposition is used to check if Euroenthusiasm depends on incumbency and the electoral calendar. Again, since the European menu is rich, different parties can choose different combinations of options that correspond not only to their ideological preferences, but also conform to their short-term strategies on the domestic scene (Neumayer 2008; Dakowska 2010). Research shows that Euroskepticism is stronger among opposition parties (De Vries - Edwards 2009; Taggart 1998). However, with the economic crisis of 2008, Euroskepticism has become increasingly mainstream (Meijers 2015; Brack - Startin 2015). Not only have radical and extreme parties increased their Euroskepticism, so have several mainstream parties, especially those that are in opposition (Conti et al. 2017). Opposition parties do not have the institutional baggage of incumbency that creates constraints on policy positions. In an attempt to challenge the incumbent government, they might project policy positions that 
are more Euroskeptic than those of cabinet parties. However, any serious shift by the governing parties towards a more anti-EU position would be damaging in terms of their public image, as it would raise questions about their credibility and capacity as domestic managers and negotiators in intergovernmental decision-making at the EU level (Hobolt and Tilley 2014). In addition, strategic knowledge might enhance the Euroenthusiasm of government parties. After all, strategic knowledge concerns the fit between procedural knowledge and contextual information and, in practice, consists of a wide range of matches across interlinking contexts: financial, cultural, political, institutional, etc. It also provides retrospective coherence and knowledge of emerging properties. In contrast, the crisis might have spurred the radicalization of the opposition, which - especially at electoral times - could use European issues as an element of disagreement with the government and seek to shift blame for hardships to the incumbents. However, amidst the growing Euroskepticism of citizens, the electoral calculus might reduce the Euroenthusiasm of both incumbent and opposition politicians. Therefore, we assume that the representatives of the opposition follow less closely the European agenda and have a lower level of Euroenthusiasm.

H5. Incumbency increases Euroenthusiasm.

Economic optimism refers to the theory of political action according to which democratic political actors react to changing economic contexts (Downs 1957). This implies a utilitarian approach to politics, and leads to the assumption that the 2008 crisis has profoundly shattered European and national economies and therefore has negatively affected Euroenthusiasm. Pre-crisis studies found a positive, but moderate relationship between citizens' satisfaction with the domestic economy and their support for the EU (Lubbers - Scheepers 2010). Public opinion data show that the economic crisis of 2008 boosted individual self-confidence and intensified feelings of personal well-being and satisfaction (Van Deth 2011, pp. 223-238), as well as sharpening the cost-benefit evaluation of the EU among ordinary citizens across Europe (Teney 2016). Thus, because of the post-crisis saliency of utilitarian approach, we expect that Euroenthusiasm will decrease more among the political elites in those countries where economic recovery is slower. By identifying a trend towards economic optimism, this indicator anticipates the reaction of elites as predicated by the economic rationality calculation model: politicians from EU member-states that financially are better off are liable to express higher Euroenthusiasm.

H6. Favorable national economic conditions increase the level of Euroenthusiasm. 


\section{EMPIRICAL RESEARCH: RESULTS AND INTERPRETATION}

In the remainder of the article, we present the results of the multiple regression analyses. The series of regression analyses we present below differentiates between the three EU regions (WE, SE and CEE). Following our model of Euroenthusiasm that differentiates between emotional and projective dimensions, we test the six hypotheses described above. All regression models use survey data from the IntUne 2007 and ENEC 2014 datasets, with additional data on economic variables and election timing coded and integrated as dummy variables.

Among the CEE elites, the main driver of Euroenthusiasm is the state of the economy. The economic crisis negatively affected Euroenthusiasm, especially its projective dimension. The effects of the economic crisis and economic optimism are insignificant in terms of the emotional component of Euroenthusiasm. Incumbent elites in the CEE are systematically more Euroenthusiastic than are representatives of the political opposition. The Euroenthusiastic bias of the incumbents endures throughout the electoral calendar. In other words, it appears that in CEE countries, political opposition does not increase its criticism of the EU in electoral campaigns.

As expected, the left-leaning elites in CEE are slightly more Euroenthusiastic (especially in terms of projective Euroenthusiasm). Meanwhile, political radicalism does not have a significant effect on elites' Euroenthusiasm in CEE. CEE elites with close working contacts with EU officials and partners are more emotionally Euroenthusiastic than those whose European contacts are weaker. The factor 'residence in the EU1' does not have a significant effect on the Euroenthusiasm of CEE elites.

The economy hugely affects the Euroenthusiasm of political elites in SE. During the economic crisis, the Euroenthusiasm of SE elites underwent significant decline, especially along the emotional dimension. However, and in contrast to the elites in CEE, in the context of economic pessimism, the SE elites further support the strengthening of the EU; i.e., their projective Euroenthusiasm has not undergone any significant decline.

In SE, incumbent elites are more Euroenthusiastic than are the representatives of political opposition. The electoral calendar does not modify this Euroenthusiastic bias of SE politicians: i.e., as in CEE, politicians in SE fail to increase effectively their criticism of the EU during electoral campaigns. Yet, in contrast to the situation in CEE, ideological preferences (left versus right) do not shape Euroenthusiasm of SE elites. However, the effects of the political extremism of SE elites' Euroenthusiasm are significant on both emotional and 
projective terms: moderate elites in SE are significantly more Euroenthusiastic. The factors of European socialization are unimportant in the Euroenthusiasm of SE elites.

Euroenthusiasm in WE is mostly driven by political factors, not by the economy. Moreover, and counter-intuitively, during the crisis emotional Euroenthusiasm slightly but significantly increased among WE elites. The two variables political ideologies and political radicalism have significant effects on the Euroenthusiasm of WE elites. The impact of ideological preferences is more pronounced and it affects both emotional and projective aspects of Euroenthusiasm; however, left-leaning elites display significantly higher levels of Euroenthusiasm. The effects of political radicalism are smaller, and mostly concern the emotional dimension of WE elites' Euroenthusiasm: politically moderate elites are more Euroenthusiastic. The positive effects of incumbency on Euroenthusiasm of WE elites are also pronounced: the emotional Euroenthusiasm of the incumbent elites is significantly stronger. In contrast to the case in CEE and SE, the electoral calculus drives the Euroenthusiasm of WE elites: in pre-electoral years, the projective Euroenthusiasm of WE elites increases. The factors of socialization do not exercise a significant effect on the Euroenthusiasm of WE elites. 
Table 3. Regression models for regions of the EU

\begin{tabular}{|c|c|c|c|c|c|}
\hline \multirow{2}{*}{ Region } & \multirow{2}{*}{\multicolumn{2}{|c|}{ Emotional }} & \multicolumn{3}{|c|}{ Model } \\
\hline & & & \multirow{2}{*}{$\begin{array}{c}\text { Projective } \\
-0,03(0,74) \\
\end{array}$} & \multirow{2}{*}{$\begin{array}{c}\text { Euroenthusiasm } \\
\mathbf{- 0 , 2 0}(0,02)\end{array}$} & \multirow[b]{2}{*}{$-0,16(0,06)$} \\
\hline \multirow{10}{*}{ 売 } & \multirow{2}{*}{ 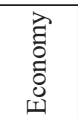 } & Crisis & & & \\
\hline & & Perceived economic & $-0,03(0,78)$ & $-0,28(0,00)$ & $-0,21(0,02)$ \\
\hline & \multirow{4}{*}{ 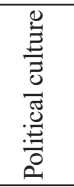 } & Political radicalism & $0,07(0,24)$ & $-0,06(0,30)$ & $0,00(0,94)$ \\
\hline & & Political ideology & $-0,02(0,71)$ & $-0,11(0,04)$ & $-0,10(0,10)$ \\
\hline & & Incumbent & $0,12(0,03)$ & $0,04(0,43)$ & $0,11(0,05)$ \\
\hline & & $\begin{array}{c}\text { Election period (pre- } \\
\text { election year) }\end{array}$ & $-0,01(0,94)$ & $0,05(0,64)$ & $0,03(0,79)$ \\
\hline & \multirow{4}{*}{. } & Residence in EU & $0,10(0,11)$ & $-0,02(0,66)$ & $0,05(0,44)$ \\
\hline & & Contact with EU officials & $0,17(0,01)$ & $0,01(0,81)$ & $0,12(0,04)$ \\
\hline & & $\mathrm{R}$ & 0,25 & 0,37 & 0,33 \\
\hline & & R square & 0,06 & 0,14 & 0,11 \\
\hline \multirow{10}{*}{ 而 } & \multirow{2}{*}{ 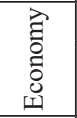 } & Crisis & $-0,33(0,00)$ & $-0,01(0,86)$ & $-0,22(0,00)$ \\
\hline & & Perceived economic & $0,27(0,00)$ & $0,08(0,13)$ & $0,22(0,00)$ \\
\hline & \multirow{4}{*}{ 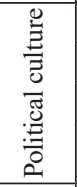 } & Political radicalism & $-0,16(0,00)$ & $-0,14(0,00)$ & $-0,19(0,00)$ \\
\hline & & Political ideology & $-0,05(0,26)$ & $-0,07(0,15)$ & $-0,08(0,09)$ \\
\hline & & Incumbent & $0,26(0,00)$ & $0,18(0,00)$ & $0,28(0,00)$ \\
\hline & & $\begin{array}{l}\text { Election period (pre- } \\
\text { election year) }\end{array}$ & $-0,06(0,13)$ & $-0,06(0,20)$ & $-0,08(0,07)$ \\
\hline & \multirow{2}{*}{ 充 } & Residence in EU & $0,05(0,24)$ & $0,04(0,37)$ & $0,06(0,18)$ \\
\hline & & Contact with EU officials & $0,06(0,11)$ & $-0,01(0,88)$ & $0,04(0,36)$ \\
\hline & & $\mathrm{R}$ & 0,45 & 0,26 & 0,43 \\
\hline & & R square & 0,21 & 0,07 & 0,18 \\
\hline \multirow{10}{*}{$\sum_{3}^{-1}$} & \multirow{2}{*}{ 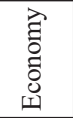 } & Crisis & $0,19(0,04)$ & $0,04(0,65)$ & $0,15(0,07)$ \\
\hline & & Perceived economic & $0,06(0,44)$ & $-0,07(0,35)$ & $0,00(0,96)$ \\
\hline & \multirow{4}{*}{ 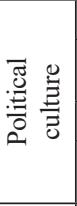 } & Political radicalism & $-0,19(0,01)$ & $-0,01(0,84)$ & $-0,14(0,04)$ \\
\hline & & $\begin{array}{c}\text { Perceived ideological } \\
\text { identity }\end{array}$ & $-0,18(0,01)$ & $-0,39(0,00)$ & $-0,37(0,00)$ \\
\hline & & Incumbent & $0,27(0,00)$ & $0,11(0,12)$ & $0,25(0,00)$ \\
\hline & & $\begin{array}{c}\text { Election period } \\
\text { (pre-election year) }\end{array}$ & $0,09(0,27)$ & $0,23(0,00)$ & $0,20(0,01)$ \\
\hline & \multirow{4}{*}{ 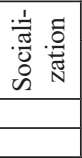 } & Residence in EU & $0,11(0,09)$ & $0,03(0,62)$ & $0,10(0,13)$ \\
\hline & & Contact with EU officials & $-0,06(0,40)$ & $0,01(0,89)$ & $-0,03(0,61)$ \\
\hline & & $\mathrm{R}$ & 0,39 & 0,40 & 0,44 \\
\hline & & R square & 0,15 & 0,16 & 0,19 \\
\hline
\end{tabular}


The findings show that regional differences produce different patterns of national elite Euroenthusiasm. The regions CEE, SE and WE vary greatly in terms of the changes in their elites' Euroenthusiasm during 2007-2014. The stress test of the economic crisis of 2008 reveals that regional histories and past legacies matter. Elites' Euroenthusiasm is positively affected by the length of EU membership (elites in WE are perceptibly more Euroenthusiastic than are elites in SE who are more Euroenthusiastic than their peers in CEE). During the 2008 crisis, the long-standing engagement of the EU founding states stabilized positive projective stances of their elites towards the EU. In contrast, in SE with social-market-oriented legacies of integration into the EU -, the projective appreciation of EU strengthening and support for the supranationalization of its policies was shattered by the 2008 crisis. As for CEE elites, who are anchored within the neo-liberal framework of thought and an economic-efficiencyoriented style of management, the 2008 crisis did not create significant barriers to their projective support for further strengthening of the EU and the increasing supranationalization of its governance.

In parallel, we observe that only in the cases of the less-developed market economies of SE and CEE are the economic crisis of 2008 per se and perceived economic factors (the economic optimism or pessimism of the population) strong predictors of the changes of elites' Euroenthusiasm. In latecomer EU memberstates from CEE, economic factors mostly affect the projective dimensions of elites' Euroenthusiasm, corresponding to the pragmatic interest-driven EU membership of post-communist countries, as observed by Haller (2008), and the more stable positive emotional texture of Euroenthusiasm that may be inferred from Gabel (1998). Findings showing that economic pessimism lowers support for the supranationalization of redistributive policies and leads to the resurgence of the nation-state are in tune with predictions about the economic theory of politics (Downs 1957), and also indicate decreasing support for current political authorities and projects when the economic outlook is poor. In SE, economic factors have strong repercussions on the emotional dimension of elites' Euroenthusiasm, and this trend somewhat contradicts the pattern observed in CEE. However, these findings corroborate the idea that the style of management of the economic crisis of 2008 could have had effects not so much on cost-benefit calculations, but on the production of strong negative emotions, reflecting the hurt feelings of the nation-state and the judgement that EU decision-making is unfair in relation to some countries. The case of SE, with its considerable decrease in emotional Euroenthusiasm driven by the ailing economy, also illustrates the importance of the emotional features of a resistance identity, described by Castells in 1997. Economic indicators are not of any significance for WE elites' Euroenthusiasm, the region with the highest level of economic 
development and with the objectively strongest resilience to the economic crisis of 2008. Thus, our research demonstrates that national economies have regionally patterned impacts on national elites' Euroenthusiasm. It appears that WE elites (and citizens whose economic optimism is measured) can de-couple their assessment of the national economic situation from their Euroenthusiasm. In WE, where the economies are most mature, economic factors play only a minimal role in Euroenthusiasm and leave ample space for the effects of political culture.

The effects of European socialization on national elites' Euroenthusiasm also lend themselves to interpretation by region. It is in newcomer CEE where networking and communication with European colleagues has a significant effect on elites' Euroenthusiasm. The Euroenthusiasm of the elite of CEE, these individuals having had relatively short exposure to Europe, is perceptibly impacted by their European contacts, and those CEE elites who have denser European networks and intensive contact with the representatives of the EU are more Euroenthusiastic. This finding is also in line with the phenomenon of strategic knowledge that underlies the positive effects of having insider status. Yet in SE and WE, where at least one generation of politicians has already been born and raised in the EU, European socialization does not play such an important role and is a simple 'fact of life'.

The greatest regional differences in changes and the plasticity of national elites' Euroenthusiasm are mediated through the effects of variables related to types of political culture. First, the difference between incumbent politicians versus opposition is significant in all three regions. These findings agree with the strategic-knowledge-based argument that insiders (i.e., committed and responsible decision-makers) possess up-to-date information that is more complete and more binding than that of outsiders. It also highlights the persistence of 'Eurelitism'; i.e., the phenomenon of elites who are not very sensitive to popular grievances yet who primarily drive the European project: across the board, incumbents display significantly higher levels of Euroenthusiasm than their political opponents do.

As is known, in all EU member states the attitude of the public towards the EU is less supportive than that of the elite. Consequently, mirroring the public voice is a strategic move that can secure popularity and increase the attractiveness of the opposition who seek to win more votes. However, the existence of preelectoral effects that diminish the government versus opposition divide, and tune all political candidates in to the public voice are found only among elites in WE. This finding might be interpreted as a sign that in WE the political culture of responsive governments is strongly developed, making political candidates sensitive to their voters (among whom Euroskepticism is increasing). The 
finding that the WE incumbents and the opposition elites adjust their stances towards the EU during national electoral campaigns also implies that in WE the EU thematic is largely employed during national electoral campaigns. In contrast, electoral effects cannot be observed among CEE and SE elites, apparently leading to much less Europeanized national electoral campaigns, and less responsivity to the increasing Euroskepticism of their constituencies.

Regionally patterned political cultures are also displayed in the differentiated impact of political ideology and political radicalism on the Euroenthusiasm of national elites. In general, our findings corroborate and develop Kopecký and Mudde's (2002) insights that the ideological dimension is dominant in Euroenthusiasm, although political strategy (here, pre-electoral calculus, political radicalism and incumbency) at times plays a role. Political ideology is systematically found to significantly affect the emotional and projective dimensions of Euroenthusiasm only in the case of the consolidated and mature democracies of WE, where leftist elites score higher on this dimension than right-wing oriented elites. The effects of ideological self-identification are also significant on the projective Euroenthusiasm of CEE elites, among whom those who hold left-leaning attitudes have higher Euroenthusiasm, as is fully compatible with expectations that left-wing politicians are more supranationally oriented and less concerned with the issues of national sovereignty that dwindle during the process of Europeanization. The political-ideological substrate is irrelevant for the Euroenthusiasm of SE elites, most probably due to the numerous government crises and tumultuous experiences of crisis management in this particular region, where post-crisis shifts in the political landscape are the most visible (Tsirbas - Sotiropoulos 2016; Magalhaes et al. 2016; Conti et al. 2017). In contrast, in SE political radicalism has a strong hold on both dimensions of national elites' Euroenthusiasm. The effects of political radicalism on the Euroenthusiasm of WE elites are smaller and visible only in the emotional dimension. Political radicalism among the national elites of CEE is negligible, and fails to produce any significant effects on their Euroenthusiasm. Indirectly but persuasively, these observations, pertinent to the Euroenthusiasm of national elites, amply illustrate the specificities of regional political cultures in the EU. WE has the most complex political culture, where national elites' electoral calculus, political ideologies, and political radicalism are profoundly intertwined and thoroughly related to their Euroenthusiasm. In contrast, after the 2008 crisis the SE elites' Euroenthusiasm (in terms of the variables of political culture) appears to be largely unidimensional and mostly dependent on political radicalism. Meanwhile, the Euroenthusiasm of CEE elites has very shallow roots in political culture - some aspects of Euroenthusiasm depend on political ideologies, but the relationship is quite spurious. These findings partly 
corroborate the claim to the absence of deep ideological political discussion and incumbent-opposition power conflict relative to the $\mathrm{EU}$ in this post-communist region which borders conflict-hungry Russia, and which struggles with major challenges (notwithstanding the effects of the crisis of 2008) that are posed by on-going socio-economic structural reforms.

In the three regions, the difference in effect of the emotional versus projective dimension are substantial: among CEE elites more malleable is the projective dimension of Euroenthusiasm; among SE elites are found the more emotional and the most balanced effects, while WE elites tap into both emotional and projective dimensions of Euroenthusiasm. As the theory of emotions (Frijda 2007) predicts, sentiment-based judgements crystalize over time and are more enduring if new negative emotions do not shatter them profoundly. In chronological terms, the newcomer CEE elites have not yet developed strong emotional relations to the EU so the projective aspect of their Euroenthusiasm prevails. Correspondingly, it is understandable why in CEE only incumbency creates significant effects on the emotional dimension of Euroenthusiasm. In comparison, the WE elites are the oldest in the club and they lead the EU project. They therefore exhibit equilibrium on the emotion-projection scale of Euroenthusiasm. Meanwhile, the emotional relation to the EU of SE elites - less well-established members of the EU - is more malleable, especially since the 2008 crisis that spurred a wave of strong negative emotions related to feelings of unfair EU decision-making at the cost of nation-state interests. These observations along the emotional-projective dimensions of Euroenthusiasm allow us to speculate about the deeply engrained regional characteristics of the Europeanness of elites and their constituencies. We take note of post-communist pragmatism and eagerness to develop a new European project-related identity. In parallel, we also observe the effects of what is popularly called 'Southern European emotionality' which in our analytical framework invites us to highlight the importance of 2008 crisis on the creation of negative emotions and hurt nation-state feelings in the social construction and maintenance of Europeanness. Finally, we are aware of the balanced nature of WE Euroenthusiasm that combines on the one hand highly politicized assessments of the need to (and interest in) strengthen(ing) EU institutions and supranationalize its policies and, on the other hand, a lively emotional texture of positive and negative feelings stemming from deeply ingrained and newly layered experiences with the EU.

Finally, the effects of European socialization on Euroenthusiasm in CEE also invite emphasis of the emotional dimension. These positive effects, found for the emotional aspect of Euroenthusiasm, show - as postulated by Schimmelfennig (2005) - that Europeanness and feelings of fairness in the decision-making of the EU are acquired and boosted "on the ground" via everyday experiences and communication. 


\section{CONCLUDING REMARKS}

The empirical study described in this paper shows that during the 2008 crisis the Euroenthusiasm of national political elites underwent changes which relate to more general than idiosyncratic country characteristics. We reveal that, even though poor overall economic performance increased negative and decreased positive dimensions of EU framing, economic factors explain only a part of the story. Counter-intuitively, and as observed by (Teney 2016), the economic crisis of 2008 augmented certain aspects of national elites' Euroenthusiasm, especially in the cases of the ongoing politicization of the EU (in WE), and of the enduring pragmatic pro-European orientation in CEE. Our findings also resonate with compelling emerging European research that demonstrates that the role of emotion should be a primary focus of attention. Moreover, the present research raises new research questions, regarding not only the (perceptions of and support for) the supranationalization of redistributive policies in the EU, but also the issues of foreign affairs and security policies, conceptualized along, on the one hand, shifting geopolitical concerns, and on the other, post-materialist considerations.

Methodologically, additional data would validate our research findings. In particular, and despite the fact that we do not have any significant reason to question the validity of elites' answers that are pertinent to political culture, deeper study of national electoral party manifestos and the analysis of political discourse would help to better address the issue of national elites' political partisanship and its relation to Euroenthusiasm. Such longitudinal, triangulated, comparative research, encompassing not only national political elites, but also ordinary citizens, may well substantiate the major findings of the present study, thereby highlighting persistent regional patterns of Europeanness.

\section{REFERENCES}

Albert, Stuart - Ashforth, Blake E. - Barker, James R. - Dukerich, Janet M. - Elsbach, Kimberly D. - Glynn, Mary Ann - Harquail, Celia V. - Kramer Roderick - McLean Judi (1998), "Identification with organizations" in: Whetten, David A. - Paul C. Godfrey, eds., Identity in organizations: Building theory through conversations, Thousand Oaks, CA, Sage Publications, Inc., pp. 209-272. http://dx.doi. org/10.4135/9781452231495.n7 
Armingeon, Klaus - Besir Ceka (2014), "The loss of trust in the European Union during the great recession since 2007: The role of heuristics from the national political system", European Union Politics Vol. 15, No 1, pp. 82-107. http://dx.doi.org/10.1177/1465116513495595

Bartolini, Stefano (2005), Restructuring Europe, Cambridge, Cambridge University Press.

Beaudonnet, Laurie - Danilo Di Mauro (2012), "Support for Europe: Assessing the complexity of individual attitudes", in: Beaudonnet, Laurie - Danilo Di Mauro, eds. Beyond Euro-skepticism: Understanding attitudes towards the $E U$, European Integration online Papers (EIoP), Special Mini-Issue 2, Vol. 16, Article 9, http://dx.doi.org/10.1695/2012009

Best, Heinrich. (2012), "Elites of Europe and the Europe of Elites: A Conclusion", in: Best, Heinrich - Gyorgy Lengyel - Luca Verzichelli, eds., The Europe of Elites. A Study into the Europeanness of Europe's Economic and Political Elites, Oxford, Oxford University Press, pp. 234-241. DOI: http://dx.doi. org/10.1093/acprof:oso/9780199602315.003.0011

Best, Heinrich (2012), "Elite Foundations of European integration: A Causal Analysis", in: Best, Heinrich - Gyorgy Lengyel - Luca Verzichelli, eds., The Europe of Elites. A Study into the Europeanness of Europe's Economic and Political Elites, Oxford, Oxford University Press, pp. 208-233. http://dx.doi. org/10.1093/acprof:oso/9780199602315.003.0010

Best, Heinrich - György Lengyel - Luca Verzichelli (eds) (2012), The Europe of Elites. A Study into the Europeanness of Europe's Economic and Political Elites, Oxford, Oxford University Press. https://doi.org/10.1093/ acprof:oso/9780199602315.001.0001

Boomgaarden, Hajo G. - Andreas R. T. Schuck - Matthijs Elenbaas -, Claes H. de Vreese (2011), "Mapping EU attitudes: Conceptual and Empirical Dimensions of Euroscepticism and EU support", European Union Politics Vol. 12, No 2, pp. 241-266. https://doi.org/10.1177/1465116510395411

Brack, Nathalie - Nicolas Startin (2015), "Introduction: Euroscepticism, from the Margins to the Mainstream", International Political Science Review Vol. 36, No 3, pp. 239-249. https://doi.org/10.1177/0192512115577231

Brader, Ted (2006), Campaigning for Hearts and Minds, Chicago, University of Chicago Press.

Bruter, Michael (2003), "Winning hearts and minds for Europe: the impact of news and symbols on Civic and Cultural European Identity", Comparative Political Studies Vol. 36, No 10, 2003, pp. 1148-1179. https://doi. org/10.1177/0010414003257609

Castells, Manuel (1997), The Power of Identity, Oxford, England, Blackwell Publishers. 
Checkel, Jeffrey T. (2005), "International Socialization and Socialization in Europe. Introduction and Framework", International Organization Vol. 59, No 4, pp. 801-826. https://doi.org/10.1017/S0020818305050289

Conti, Nicolò - Giorgos Charalambous - Andrea Pedrazzani (2017 forthcoming), The political contestation of European integration in southern Europe: A story of friction among and within parties, Party Politics,

https://www.academia.edu/33434986/The_political_contestation_of_ European_integration_in_southern_Europe_A_story_of_friction_among_ and_within_parties

Conti, Nicolo - Maurizio Cotta - Pedro Tavares de Almeida (2010), "Southern Europe: A Distinctive and More Pro-European Region in the EU?", South European Society and Politics Vol. 15, No 1, pp. 1-10. https://doi.org/10.1080 /13608746.2010.496918

Cotta, Maurizio - Federico Russo (2012), "Europe À La Carte? European Citizenship and its dimensions from the perspective of national elites", in: Best, Heinrich - Gyorgy Lengyel - Luca Verzichelli, eds., The Europe of Elites. A Study into the Europeanness of Europe's Economic and Political Elites, Oxford, Oxford University Press, pp. 14-42. http://dx.doi.org/10.1093/ acprof:oso/9780199602315.003.0002

Dakowska, Dorota (2010), "Whither Euroscepticism? The Uses of European Integration by Polish Conservative and Radical Parties", Perspectives on European Politics \& Society Vol. 11, No 3, pp. 254-272. https://doi.org/10.108 $0 / 15705854.2010 .503032$

De Vries, Catherine - Erica. E. Edwards (2009), "Taking Europe to its Extreme: Extremist Parties and Public Euroscepticism", Party Politics Vol. 15, No 5, pp. 5-28. https://doi.org/10.1177/1354068808097889

De Wilde, Pieter (2011), "No Polity for Old Politics? A Framework for Analyzing the Politicization of European Integration", Journal of European Integration Vol. 33, No 5, pp. 559-575. http://dx.doi.org/10.1080/07036337.2010.546849

De Wilde, Pieter - Michael Zurn (2012), "Can the politicization of European integration be reversed?", Journal of Common Market Studies Vol. 50, pp. 137-153. http://dx.doi.org/10.1111/j.1468-5965.2011.02232.x

Deaux, Kay (1996), "Social Identification", in Higgins, Torry E. - Arie W. Kruglanski, eds., Social psychology: Handbook of basic principles, New York, Guilford Press, pp. 777-798.

Downs, Anthony (1957), "An Economic Theory of Political Action in a Democracy", Journal of Political Economy Vol. 65, No 2, pp. 135-150. https:// doi.org/10.1086/257897

Frijda, Nico H. (2007), The Laws of Emotion, Mahwah, N.J., Lawrence Erlbaum Associates. 
Gabel, Matthew (1998). "Public Support for European Integration: An Empirical Test of Five Theories“, The Journal of Politics, Vol. 60, No. 2, pp. 333-354. http://www.jstor.org/stable/2647912

Ginsberg, Roy H. (2010), Demystifying the European Union: the Enduring Logic of Regional Integration, Lanham, Rowman \& Littlefield Publishers.

Gross, Kimberly (2008), "Framing Persuasive Appeals: Episodic and Thematic Framing, Emotional Response, and Policy Opinion”, Political Psychology Vol. 29, No 2, pp. 169-192. https://doi.org/10.1111/j.1467-9221.2008.00622.x Hay, Colin (2004), "Common Trajectories, Variable Paces, Divergent Outcomes? Models of European Capitalism under Conditions of Complex Economic Interdependence", Review of International Political Economy Vol. 11, No 2, pp. 231-262. http://dx.doi.org/10.1080/09692290420001672796

Hall, Peter A. - David Soskice (2003), Varieties of Capitalism: The Institutional Foundations of Comparative Advantage, Oxford: Oxford Scholarship Online. : http://dx.doi.org/10.1093/0199247757.001.0001

Haller, Max (2008), European Integration as an Elite Process. The Failure of a Dream?, New York, Routledge.

Hancké, Bob - Martin Rhodes - Mark Thatcher (eds). (2007), Beyond Varieties of Capitalism: Conflict, Contradictions, and Complementarities in the European Economy, New York, Oxford University Press.

Hobolt, Sara B. - James Tilley (2014), Blaming Europe? Responsibility without Accountability in the European Union, Oxford, Oxford University Press.

Hooghe, Liesbet - Gary Marks - Carole J. Wilson (2002), "Does Left/Right Structure Party Positions on European integration?, Comparative Political Studies Vol. 35, No 8, pp. 965-989. https://doi.org/10.1177/001041402236310 Hooghe, Liesbet - Gary Marks - Moira Nelson - Erica Edwards (2006), "Party Competition and European Integration in East and West: Different Structure, Same Causality, Comparative Political Studies Vol. 3, No 2, pp. 155-175. https://doi.org/10.1177/0010414005281932

Huddy, Leone - Feldman Stanley - Cassese Erin (2007), "On the distinct political effects of anxiety and Anger", in: Neuman, Russel W. - George E. Marcus - G, Ann N. Crigler - Michael MacKuen,, eds., The Affect Effect: Dynamics of Emotion in Political Thinking and Behaviour, Chicago, University of Chicago, pp. 202-230.

Kaina, Viktoria - Ireneusz Pawel Karolewski - Sebastian Kuhn (2016), European Identity Revisited- New Approaches and Recent Empirical Evidence, London and New York, Routledge.

Katz, Richard S. (1991), "Materialists and Postmaterialists: Different Viewpoints or Different Worlds?" in: Inglehart, Ronald - Reif Karlheinz, 
eds., Eurobarometer. The Dynamics of European Public Opinion Essays in Honour of Jacques-René Rabier, Palgrave, Macmillan, pp. 295-307.

Kopecky, Petr - Cas Mudde (2002), "The Two Sides of Euroscepticism: Party Positions on European Integration in East Central Europe", European Union Politics Vol.3,No.3,pp.297-326.https://doi.org/10.1177/1465116502003003002 Lazić, Mladen - Miguel Jerez-Mir - Vladimir Vuletić - Rafael Vásquez-Garzia (2012), "Patterns of Regional Diversity in Political Elites' Attitudes", in: Best, Heinrich - Gyorgy Lengyel - Luca Verzichelli, eds., The Europe of Elites. A Study into the Europeanness of Europe's Economic and Political Elites, Oxford, Oxford University Press, pp. 147-166. http://dx.doi.org/10.1093/ acprof:oso/9780199602315.003.0007

Lengyel, György - Borbála Göncz (2009), "Elites' Pragmatic and Symbolic Views about European Integration", Europe-Asia Studies Vol. 61, No 6, pp. 1059-1077. http://dx.doi.org/10.1080/09668130903063674

Lubbers, Marcel - Peer Scheepers (2010), "Divergent Trends of Euroscepticism in Countries and Regions of the European Union, European Journal of Political Research Vol. 49, No 6, pp. 787-817. http://dx.doi.org/10.1111/j.14756765.2010.01915.x

Magalhaes, Pedro - Joao Cancela - Catherine Moury (2016), "Scattered Clouds in the Horizon of Consensus: Attitudes of Portugese Parliamentary Elites Towards Europe before and After the Crisis", Historical Social Research Vol. 41, No 158, pp. 173-194. http://dx.doi.org/10.12759/hsr.41.2016.4.173-194

Magone, José M. (2003), The Politics of Southern Europe. Integration into the European Union, Westport, Praeger.

Magone, José M. (2011), "Centre-Periphery conflict in the European Union? Europe 2020, the Southern European Model and the euro-crisis", in: Ágh, Attila, ed., European Union at the Crossroads: the European Perspectives after the Global Crisis, Budapest, Budapest College of Communication, Business and Arts, pp.71-122.

Matonytė, Irmina - Vaidas Morkevičius (2013), Elitu Europa: tapatybiu ir interesu kaleidoskopas, Vilnius, Firidas.

Mau, Steffen - Roland Verwiebe (2010), European societies: mapping structure and change. Bristol, Policy.

Medrano, Juan Diez (2010), "Unpacking European Identity", Politique Européenne Vol. 1, No 30, pp. 45-66. http://dx.doi.org/10.3917/poeu.030.0045

Meijers, Maurits J. (2015), "Contagious Euroscepticism: The impact of Eurosceptic Support on Mainstream Positions on European Integration, Party Polytics Vol.23, No 4,pp.413-423. http://dx.doi.org/10.1177/1354068815601787 Neumayer, Laure (2008), "Euroscepticism as a political label: The use of European Union issues in political competition in the new Member States", 
European Journal of Political Research Vol. 47, No 2, pp. 135-160. http:// dx.doi.org/10.1111/j.1475-6765.2007.00721.x

Nölke, Andreas - Arjan Vliegenthart (2009), "Enlarging the Varieties of Capitalism. The Emergence of Dependent Market Mconomies in East Central Europe". World Politics Vol. 61, No 4, pp. 670-702. http://dx.doi.org/10.1353/ wp. 0.0039

Ó Beacháin, Donnacha - Vera Sheridan - Sabina Stan (eds.) (2012), Life in Post-communist Eastern Europe after EU Membership, New York, Routledge. Pop-Eleches, Grigore - Joshua A. Tucker (2017), Communism's Shadow: Historical Legacies and Contemporary Political Attitudes, Princeton, Princeteon University Press.

Real-Dato, José - Borbála Göncz - György Lengyel (2012), "National Elites' Preferences on the Europeanization of Policy-Making", in: Best, Heinrich - Gyorgy Lengyel - Luca Verzichelli, eds., The Europe of Elites. A Study into the Europeanness of Europe's Economic and Political Elites, Oxford, Oxford University Press, pp., 67-93. http://dx.doi.org/10.1093/ acprof:oso/9780199602315.003.0004

Recchi, Ettore (2014), "Pathways to European Identity Formation: a Tale of two Models", Innovation: The European Journal of Social Science Research Vol. 27, No 2, pp.119-133. http://dx.doi.org/10.1080/13511610.2013.873709

Risse, Thomas - Jana Katarina Grabowsky (2008), "European Identity Formation in the Publc Sphere and in Foreign Policy", RECON Online Working Paper 4, http://www.polsoz.fu-berlin.de/polwiss/forschung/international/ atasp/publikationen/4_artikel_papiere/2009_paper_TR_european_identity_ formation/RECON_wp_0804.pdf

Rohrschneider, Robert, - Stephen Whitefield (2016), "Responding to growing European Union-skepticism? The stances of Political Parties Toward European Integration in Western and Eastern Europe Following the Financial Crisis, European Union Politics Vol. 17, No 1, pp.138-161. https://doi. org/10.1177/1465116515610641

Sanders David - Paolo Bellucci - Gabor Toka - Mariano Torcal (2012), The Europenziation of National Politics? Ctizenship and Support for a Postenlargement Union, Oxford, Oxford University Press.

Sartori, Giovani (1970), "Concept Misformation in Comparative politics", The American Political Science Review Vol. 64, No 4, p. 1033-1054. https://doi. org/10.2307/1958356

Schimmelfennig, Frank (2005), "Strategic Calculation and International Socialization", International Organization Vol. 59, No 4, pp.827-860. https:// doi.org/10.1017/S0020818305050290 
Schubert, Klaus - Simon Hegelich - Ursula Bazant (eds.) (2009), The Handbook of European Welfare Systems, London and New York, Routledge.

Serricchio, Fabio - Myrto Tsakatika - Lucia Quaglia (2013), "Euroscepticism and the Global Financial Crisis", Journal of Common Market Studies Vol. 51. No 1, pp. 51-64. https://doi.org/10.1111/j.1468-5965.2012.02299.x

Sitter, Nick. (2001), "The Politics of Opposition and European Integration in Scandinavia: Is Euro-skepticism a Government-Opposition Dynamic?, West European Politics Vol. 24, No 4, pp. 22-39. http://dx.doi. org/10.1080/01402380108425463

Słomczynski, Kazimierz M. - Włodzimierz Wesołowski, W. (2010), "Policy Preferences among National Elites Regarding Allocation of Tax-Revenues: Are Pro-EU Attitudes More Pronounced in Older Democracies?", Perspectives on European Politics and Society Vol. 11, No 4, pp. 374-389. http://dx.doi.or $\mathrm{g} / 10.1080 / 15705854.2010 .524409$

Snow, David (2001), "Collective Identity and Expressive Forms", Center for the Study of Democracy Working Papers, University of California, Irvine Publication, http://escholarship.org/uc/item/2zn1t7bj

Sojka, Aleksandra - Besir Ceka (2016), "Loving it but not Feeling it yet? The State of European Identity after the Eastern Enlargement", European Union Politics Vol. 17, No 3, pp. 482-503. https://doi.org/10.1177/1465116516631142

Steen, Anton (2015), "Small States and National Elites in a Neoliberal Era", in: Baldersheim, Harald - Michael Keating, eds., Small States in the Modern World. Vulnerabilities and Opportunities, Chetlenham, Edward Elgar Publishing, pp.183-201.

Steenbergen, Marco R., - Gary Marks (2004), "Introduction: Models of Political conflicts in the European Union", in: Steenbergen, Marco R. - Gary Marks, eds., European Integration and Political Conflict, Cambridge, Cambridge University Press, pp. 1-10.

Taggart, Paul (1998), "A Touchstone of Dissent: Euroscepticism in Contemporary Western European Party Systems", European Journal of Political Research Vol. 33, No 3, pp. 363-388. http://dx.doi.org/10.1111/1475-6765.00387

Tajfel, Henri (1978), Differentiation between social groups: Studies in the Social Psychology of Intergroup Relations, London, Academic Press.

Teney, Céline (2016), "Does the EU Economic Crisis Undermine Subjective Europeanization? Assessing the Dynamics of Citizens' EU Framing between 2004 and 2013", European Sociological Review Vol. 32, No 5, pp. 619-633. https://doi.org/10.1093/esr/jcw008

Tsirbas, Yannis - Dimitrii A.Sotiropoulos (2016), "Europe at the Epicenter of National Politics: The attitudes of Greek Political Elites towards the European 
Union and the Economic Crisis", Historical Social Research, Vol. 41, No 158, pp. 86-105. http://dx.doi.org/10.12759/hsr.41.2016.4.86-105

Van Deth, Jan W. (2011), "The Impact of the Economic Crisis in Europe: „I am doing fine"“", in: Rosema, Martin - Bas Denters - Aarts Kees, eds., How Democracy Works. Political Representation and Policy Congruence in Modern Soceties, Amsterdam, Amsterdam University press, pp. 223-237.

Vaughan-Whitehead, Daniel C. (2003), EU Enlargement versus Social Europe? The Uncertain Future of the European Social Model, Cheltenham, Edward Elgar Publishing.

Vogel, Lars - Teruel Juan-Rodriguez (2016), "Staying on course in Turbulent Times National Political Elites and the Crisis of European Integration", Historical Social Research Vol. 41, No 158, pp. 7-37. http://dx.doi.org/10.12759/ hsr.41.2016.4.7-37 
